Маја Радонић

UDC: $316.774: 004.738 .5$

UDC: $371.3:: 821]: 004.738 .5$

DOI: $10.18485 /$ dh.2015.2.ch9

\title{
ДИГИТАЛНИ МЕДИЈИ И КЊИЖЕВНОСТ: КЊИЖЕВНИ КЛАСИЦИ НА ДРУШТВЕНИМ МРЕЖАМА
}

\section{Сажетак}

Дигитална технологија отворила је готово неограничено поље за нове могућности стварања и преношења информација и разноликих садржаја уз помоћ дигиталних медија. У виртуелном простору интернет мреже, поред доминантних забавних и информативних садржаја, своје место проналазе дела и ствараоци трајних културних вредности, попут књижевних класика. Кроз приказ странице на друштвеној мрежи Фејсбук посвећене великом српском писцу Меши Селимовићу настоји се утврдити да ли и на који начин хипермедиј коју представља ова интерактивна страница проширује комуникационо поље дела једног књижевног класика, да ли доприноси дубљем разумевању одређеног садржаја високе културе, те у којој мери носи потенцијалну опасност његовог површног, масмедијског интерпретирања? Другачије речено: да ли у савременом интерактивном окружењу хипермедија класици културе могу постати потрошни медијски садржај и да ли оно утиче на промену рецепције књижевног дела?

Кључне речи: дигитални медији, интерактивност, интернет, Меша Селимовић, Фејсбук, књижевност, рецепција

На друштвеним интернет мрежама попут Фејсбука, између осталих претежно забавних садржаја, налазе се и странице посвећене значајним културним ствараоцима. Када је реч о Фејсбуку на српском језику, међу ствараоцима културе доминирају странице посвећене познатим српским писцима, првенствено онима који спадају у класике, попут Иве Андрића, Милоша Црњанског, Јована Дучића, Момчила Настасијевића, Меше Селимовића и других. Тако поред званичне књижевноисторијске и теоријске рецепције дела Меше Селимовића у нашој стручној и културној јавности, постоји широко и разгранато поље рецепције његовог дела и личности међу читалачком публи- 
ком, у распону од љубитеља књижевности, преко читалаца његових есеја и поштовалаца његових политичких и филозофских идеја, све до оних који се највише баве познатим и мање знаним детаљима Селимовићевог личног живота, друштвеном каријером или питањем националног идентитета.

Ово шаролико друштво љубитеља писане речи налази се између осталог у виртуелном окружењу друштвене мреже Фејсбук, на страници названој Меша Селимовић - писац, основаној 2012. године, ${ }^{1}$ а према подацима у моменту настајања текста страница има 306.145 "свиђања", што значи особа које су макар једном отвориле ову страницу, нешто прочитале и кликнуле на иконицу "свиђа ми се", уз 31.533 особа које "причају о овоме", што значи да се укључују у дискусије на страници. Пред нама је очигледно пример хипертекста, који дефинишемо као текст представљен на рачунару који садржи линкове ка другим текстовима, а будући да укључује и слике, видео, анимацију и звук, прецизније ћемо га дефинисати појмом хипермедија - текстом који обухвата и додатне медијске садржаје. Иманентно својство хипермедија је интерактивност, посебна врста дијалога између корисника и апликације, те хипермедиј од корисника захтева активност, будући да су хипермедијске теме повезане и корисник у потрази за информацијом прелази са текста/предмета на други повезани текст/предмет.

У уводном делу својих Cјећања, Меша Селимовић наводи да га је на писање ових сојеврсних мемоарско-аутобиографских записа подстакло, између осталог, и писмо једне ученице четвртог разреда основне школе из којег је видљиво да она не разликује награђеног писца од награђеног ученика, што га наводи да резигнирано утврди како "стварно неписмених у Југославији има преко 20.000.000", тј. оних "који не знају ни за наше књиге, ни за нас, ни за наше проблеме". (Селимовић, 1976:7) Јасно је да на овом месту велики писац говори заправо о својој бризи за сећање, за трајање, о напору да се остави траг, као и о вечитој борби са самим собом коју пролази сваки стваралац питајући се да ли оно што жели да пренесе људима дола-

1 https://www.facebook.com/Mehmed.Mesa.Selimovic/?fref=ts (приступљено 31.август 2016.године) 
зи до њих и има ли смисла бавити се уметношћу у свету који делује равнодушно и заокупљено оним што зовемо свакодневни живот. Упркос овој резигнираној пишчевој опасци о "20.000.000 оних који не знају за наше књиге", дело Меше Селимовића је веома широко прихваћено међу читаоцима, о чему сведочи и импозантна бројка од преко 300.000 пратилаца Фејсбук странице посвећене управо његовом делу, уз напомену да ова страница није једина страница на овој друштвеној мрежи која се бави њиме, него је одабрана за овај рад као репрезентативна због највећег броја људи који су укључени у дискусије. Посебно место Мешиних романа у српској књижевности и међу читаоцима истиче Александар Јерков у тексту "Културна поетика прозе Меше Селимовића", наводећи "како се о Мешиним романима говори једним посебним тоном", уз занимљиво запажање како је "можда осећање велике бликости које његове књиге изазивају разлог томе што је његов надимак тако дубоко продро у књижевну подсвест". (Јерков, 2010: 189) О осећању блискости које наводи Јерков и које осећају његово читаоци, сведоче и записи посетилаца ове странице, махом заљубљеника у речи које је у својим романима и прози записивао Мехмед Меша Селимовић.

У овом раду смо се бавили питањем да ли и на који начин хипермедиј попут ове интерактивне странице на друштвеној мрежи проширује комуникационо поље дела једног књижевног класика, у овом случају Меше Селимовића, да ли доприноси дубљем разумевању одређеног садржаја високе културе, а у којој мери носи потенцијалну опасност његовог површног, масмедијског интерпретирања? Другачије речено: да ли у савременом интерактивном окружењу хипермедија класици културе постају потрошни медијски садржај? Поред наведеног, настојали смо да увидимо у каквом односу се налазе стручна рецепција и оцена Селимовићевог дела и рецепција широке читалачке публике, где су евентуална подударања у ставовима, а где је највећи раскорак? Током интерпретације основних проблемских оквира, наметнуло се теоријско питање прворазредног значаја, које ће свакако послужити као полазиште неких будућих истраживања, а на које ћемо се овом приликом само осврнути, а то је у којој мери један хипермедиј попут овакве интернет 
странице представља нови облик интертекста, који је настао и настаје и даље у променљивом интерактивном окружењу? Будући да појам интертекста, као и саме интертекстуалности добија нова тумачења и интерпретације од како га је формулисала Јулија Кристева 1966, а разрадио Ролан Барт на темељима Де Сосирове тезе о произвољности језичког знака и проучавања дијалогизма у књижевности Михаила Бахтина, ${ }^{2}$ интертекст ћемо посматрати на темељу Бартове тезе као читаочеву перцепцију веза између дела и других дела која му претходе или му следе и накнадне прецизније дистинкције између појмова интертекстуалности и интертекста коју 1979. уводи Мишел Рифатер. ${ }^{3}$ Управо овако дефинисан интертекст доследно се открива проучавањем интерактивне странице посвећене једном писцу, и тако кроз конкретан пример потврђује теоријски постављен и дефинисан појам, и представља драгоцен путоказ за нова истраживања.

На друштвеној мрежи Фејсбук постоји неколико страница посвећених Меши Селимовићу, ${ }^{4}$ а за овај рад изабрали смо репрезентативну страницу која има убедљиво највећи број посетилаца којима се страница свиђа (преко 300.000), константну активност од дана оснивања 2012. године, као и највећи број корисника активно укључених у дискусије на страници (31.533 у тренутку настајања тек-

Појам интертекст у науку у књижевности уводе теоретичари постструктуралисти, а формулисала га је Јулија Кристева1966. на семинару код Ролана Барта, који ће потом кључно допринети настанку и даљем развоју овог теоријског појма. Његово схватање интертекста налазимо у познатом ставу изнетом 1968. у делу Смpm aymopa ("La mort de l'auteur"): "Читатељ је простор на којему су сви цитати који чине писање записани, а да при томе ниједан од њих није изгубљен: јединство текста не лежи у његову поријеклу, него у његову одредишту. Но то одредиште више не може бити особно: он је једноставно онај нетко који садржи на једном мјесту све трагове од којих се писани текст састоји". (Барт: 1986:50)

3 Према прецизној Рифатеровој дистинкцији "интертекстуалност је модалитет перцепције, одгонетање текста што га врши читалац на тај начин што идентификује структуре којима текст дугује својства уметничког дела", док је интертекст "корпус текстова које читалац може основано повезати са текстом пред својим очима, то јест, то су текстови на које се подсетио док чита." (Ерор, 2002:248-249)

4 Поред странице која је предмет нашег истраживања, на Фејсбуку на српском језику постоје и странице Мехмед Меша Селимовић - писац (176.657 пратилаца), Меша Селимовић -цитати који живе (49.594 пратилаца), Меша Селимовић - писац (56.155 пратилаца), Дервиш и смрт - Меша Селимовић (11.820 пратилаца), Тврђава - Меша Селимовић (6.325 пратилаца), Круг - Меша Селимовић (114 пратилаца) и друге. 
ста). На насловној страни ове хипермедије Меша Селимовић је ближе одређен као писац и филозоф, а међу основним информацијама налази се и његова краћа биографија са нешто библиографских података, што може навести на закључак да страницу није основао неки стручњак из области науке о књижевности, већ неки љубитељ писане речи, посебно Селимовићевог дела, солидног просечног образовања. Доминантни садржај странице чине "постови" администратора - текстови и одабрани цитати из Селимовићевих прозних дела, затим неколико фотографија из различитих животних периода, фотографије његове породице и пријатеља, и понеки аудио-видео снимак. Наведене садржаје активно коментаришу или подржавају "свиђањима" корисници странице, постављају, деле и препоручују их другим корисницима преко својих Фејсбук страница, тако да пред собом имамо пример интерактивног хипермедија, онако како смо га дефинисали у уводном делу рада. Будући да би детаљна анализа свих постављених садржаја, коментара и дељења на друге интернет странице захтевала обимну интердисциплинарну студију, ограничили смо поље нашег истраживања у првом реду на текстуалне садржаје које поставља креатор странице - администратор и коментаре који их прате, а потом издвојили текстове који се најчешће понављају и имају највише карактеристичних коментара, уз фокус на оне који пружају одговоре на питања из уводног дела која смо поставили као циљ истраживања.

Већ при летимичном читању Фејсбук странице Меша Селимовић уочава се први видљиви раскорак између стручне и популарне рецепције његовог дела - док књижевна критика и стручна јавност на сасвим други начин сагледава Селимовићево дело, пратећи негове наратолошке, текстуалне, стилске, идејне и идеолошко-филозофске равни и то са тежиштем на ремек-дело Дервиш и смрт, дотле група на Фејсбук страници пажњу управља на цитате и популарне "мудре мисли" истргнуте из контекста, претежно из романа Тврђава, мемоарске шрозе Сјећања и романа Круг, а следе их цитати из Острва и Магле и мјесечине и романа Дервиш и смрт. Морамо на овом месту подсетити на познату чињеницу да је раскорак у рецепцији дела одређеног уметника између стручне јавности и широке публике пре правило него изузетак, али и да се најчешће јавља 
при рецепцији целокупног дела одређеног уметника, тако да дела појединих врхунских уметника никада не доживе широку рецепцију, упркос највишим вредносним судовима стручњака и обрнуто - често ниско оцењени аутори постају најшире прихваћени. Пример поезије Момчила Настасијевића можда најбоље сведочи о горе наведеном случају, барем када је српска књижевна традиција у питању. Горе истакнути став стручне и критичке јавности према роману Дервиш и cмpm у односу на остала Селимовићева дела објашњава донекле и Марко Крстић у тексту "Круг или финале породичног усуда": „Зашто се о Селимовићевом Кругу писало толико мало или се није писало уопште, остаће вечита енигма за српску књижевност. Многи ће одговор потражити у аргументацији да је Круг уметнички слабији роман и од Дервиша и од Тврђаве. И да је у односу на њих, Круг мали роман, да не кажем, мала ствар. (...) У односу на Дервиша сићушан, на Тврђаву неприметан, али поетички несагледиво важан. На крају, зашто би Круг морао бити на висинама једног Дервиша?“ (Крстић. 2010:65)

Дело Меше Селимовића је очигледно прихваћено како код најширег круга читалаца, тако и у научној и стручној јавности, те право питање није постојање и квантитет те рецепције, већ њен квалитет и природа у интерактивном окружењу хипермедије. Следствено томе, тражили смо и маркирали места на којима је рецепција Селимовићевог дела код читалаца у највећем раскораку са стручним оценама, а затим места на којима се рецепција подудара, где постоји евентуално сагласје у оценама стручњака и читалаца. Очекивано је било да цитати из најпознатијег Мешиног дела Дервиш и смрт доминирају по броју цитата на популарној друштвеној мрежи, али очигледно је да се посетиоци странице највише баве цитатима из романа Тврђава, змемоарске прозе Сјећања и романа Круг, што наводи на закључак да је целокупно дело Меше Селимовића широко прихваћено и познато и да се његови љубитељи баве и мање познатим и признатим делом његовог опуса. Ово свакако није очекивано, а упућује на мисао да је питање рецепције уметничког дела још увек недовољно истражено подручје и да очекивано поље рецепције једног дела не мора да се подудара са стварном рецепцијом, и да 
га је готово немогуће прецизније пројектовати. У сваком случају, овај условно речено раскорак између стручне и читалачке рецепције када је у питању избор дела једног писца, указује да је бојазан коју је Селимовић изразио у горе наведеним речима из уводног дела Сјећања, питајући се да ли икога занима оно што говори кроз своје књиге, на његову и нашу срећу, била неоснована. Усудили бисмо се и да кажемо како би свакако био обрадован овако широким и разгранатим пољем рецепције које његово дело ужива. Са тог аспекта гледано, иако уочени раскорак између стручне и широке рецепције постоји на овом месту, он не упућује на неподударање у вредносним оценама Селимовићевог дела, већ на разлику у избору дела која се високо вреднују. При томе не можемо занемарити ни да овакве странице предстваљају израз модерне свести корисника интерактивних мрежа, у времену које литературу перципира првенствено као ексклузивни предах и краткотрајни излет у лирска или контемплативна стања, па не можемо ни очекивати продубљене увиде или књижевнотеоријске расправе у интернет окружењу.

У својим романима и есејима Меша Селимовић често промишља опште теме људске егзистенције попут љубави, пролазности, младости, старости, смрти, пријатељства, али и филозофске, историјске, националне и политичке теме, а у већини цитата-постова на страници доминирају његове мисли о љубави, затим о мушко-женским односима и пријатељству, а следствено томе изазивају и највише коментара посетилаца. Коментари се крећу од апсолутног слагања са написаним, уз кратко "геније", "историјска мисао", "један је Меша", до псеудофилозофских разматрања и навођења цитата из других Мешиних дела, уз ређе критичко преиспитивање наведеног, које по правилу бива пропраћено правим малим полемикама. Тако на пост администратора који чини кратак цитат из Круга: "Људску затвореност може разбити само љубав" при заласку сунца, ређају се коментари "хм..", "тешко", "слажем се", "величанствено", до правих малих исповести о сопственом љубавном искуству, најчешће несрећном. Сасвим очекивано, Селимовићеве

5 Сви цитати са странице наведени према извору https://www.facebook.com/Mehmed. Mesa.Selimovic/?fref=ts (приступљено 31.август 2016.године) 
мисли и ставови о женама истргнути из контекста, изазивају праве мале мушко-женске ратове у коментарима, али видљив је велики утицај његових речи на читаоце, и њихово прихватање као коначних и неопозивих истина.

Из овог корпуса издвојили смо карактеристичан пример цитата из последњег Мешиног романа Круг: „Када заиста неког волиш, онда га не доживљаваш само као продужетак себе. Не волиш га само због себе. Љубав је када знаш да пустиш“, који се често понавља на страници и изазива мноштво коментара. Коментатори се на различите начине укључују у дискусију, поткрепљујући изречено другим цитатима из Селимовићеве прозе, цитатима Достојевског, Маркеса, сопственим размишљањима и питањима, или изражавају неслагање са изреченим, неретко ступајући у дијалог са другим коментатором. У вишегласју коментара издвајају се понекад оригинални гласови који по правилу ступају у дијалог са писцем, а ређе са осталим коментаторима, како је уобичајено, и тако настају праве мале исповести проткане псеудофилозофским мислима, али и полемичким ставом. Оно што је карактеристично за многе коментаре је да су изречени спонтано, да се "обраћају" директно писцу као неком ко је истински присутан на страници попут осталих учесника: "Зар је и то мерило љубави? Питам се? Неки нови тренд? Занимљиво..", или пак изражавају слагање са јасно исказаном свешћу о дистанци: "Да, истина. Слажем се са констатацијом писца. То је љубав када знаш када треба пустити. Љубав није посједовање". Један корисник странице пише коментар, обраћајући се директно и присно писцу: "Е мој Мешо... љубав се не пушта шефе...промашај". "Разговор" наставља цитирајући Селимовићу његове сопствене речи о жени из романа Тврђава које су противречне наведеном цитату и закључује питањем директно упућеном песнику: "И где је ту сада већа истинитост према самом себи?!?!?!" Овакав начин коментарисања, уз неизбежан осмех који изазива, указује на интертекстуални потенцијал хипермедије и наводи на закључак да је интертекстуалност једно од основних и изразитих својстава хипертекста или хипермедије, а када њен предложак чини књижевни текст као у овом конкретном случају, настаје један нови интертекст подложан сталним променама и новим тумачењима. 
Питање на које треба обратити пажњу јесте на који начин овај нови и покретљиви интертекст утиче на свој предложак, књижевни текст од којег полази и потенцијално га мења, као и који од текстова забележених на интерактивној страници чине интертекст? Важно је нагласити да не садржи сваки коментар интертекстуални потенцијал, већ само онај који ступа у активни дијалог са текстом и без обзира на стилске и изражајне неусаглашености, утиче на даљу рецепцију основног текста.

Са позиције интертекстуалности анализирана је и структура цитата постављених као одговор на одређену тему поста, и ту такође доминирају цитати из других дела самог Селимовића, који или потврђују и поткрепљују наведено, или пак преиспитују речено, тако да добијамо два типа метатекста - у првом читалац поставља самог песника у сагласје са својим речима, док у другом поставља песника у полемички контекст са сопственим делом, као у горе наведеном примеру. Од цитата из дела других књижевника као одговор Селимовићевим текстовима, појављају се Андрићеве и Дучићеве мудре мисли, цитати из дела Његоша, Достојевског, Толстоја, Маркеса, и они по правилу не полемишу са његовим речима, већ проширују, допуњују или додатно тумаче наведено. Тако наилазимо на један од коментара на цитат о жени у облику непрецизно наведених Његошевих стихова, вероватно по сећању: "Женскија је ћуд смијешна работа, стотину ће промијенити вјера да учини што јој срце ишће. Његош", а који се по смислу уклапа у наведени цитат. Очигледно је да по неком неизреченом правилу, љубитељи дела Меше Селимовића који посећују страницу, не полемишу са пишчевим речима наводећи текст неког другог писца да поткрепи неслагање, већ у том случају наводе неки други његов текст или сопственим речима ступају у критички дијалог са песником. Може се претпоставити да је у питању специфичан начин изражавања одређене врсте лојалности према омиљеном писцу, чије дело на неки начин "штите" од евентуалних аргументованих контра-ставова других значајних уметника речи.

У сваком случају, анализа прозних цитата који доминирају на овој интерактивној страници, њихов избор, најчешће теме и текстови коментара који их прате, потврђују да је кроз Сјећања, Круг и Тврђаву, 
велики писац проговорио језиком блиском бројним читаоцима, о темама које вечно заокупљају људско биће у потрази за одговорима о смислу егзистенције и мистерији човековог трајања и нестајања, тако да се и дискусије које иницирају цитати из овог дела у најмањој мери могу назвати књижевним, пре псеудофилозофским разматрањима вечних тема. Може се рећи да у великој мери Селимовићеве мисли иницирају саморефлескије корисника активних на страници, а тек донекле проширују рецепцију његовог дела и упућују на неке друге писце који су у сагласју са основним тоном и темама наведених текстова.

Важно је истаћи и промену у рецепцији тема које се налазе у фокусу читалачке пажње, тако да је на овој страници видљиво одсуство националних и политичких тема из Селимовићевих прозних текстова, као и спорадично цитирање овог тематског круга. Међутим, у случају националних и политичких тема, није сигурно да је у питању подударност суда критике и читалаца, већ очигледна засићеност и замор читалаца од тема које су апсолутно доминирале медијима, форумима и интернет страницама у претходне две деценије, а кореспондирале су са друштвеном климом поновног буђења националне свести, ратног окружења, преиспитивања идеолошких догми социјализма, што је будило и нарочито интересовање за табу теме и ствараоце, међу које је свакако спадао и Меша Селимовић. Очекивано, овде се ради о коментарима на познато тестаментарно писмо упућено САНУ о српском националном опредељењу Меше Селимовића, што изазива и изазиваће и даље очигледно, бројна неслагања и неразумевање. Само на једном месту на страници је постављен текст овог писма, али свакако довољно за бројне реакције. Ради презицнијег илустровања оваквог вида полемике, или малог интернет рата боље речено, наводимо изузетно на овом месту у раду и имена учесника, те оригинално писмо и правопис на коме су појединачни коментари написани, јер јасно указују на линију раздвајања између њих:

Миљан Максимовић: "један је једини Меша Селимовић...Делија са севера:)добрица и мудрац:)". Merima Lagumdzija: "Divan pisac koji na zalost nikad nije imao slododu rijeci". Kadiric Nedim: "vrhunski pisac.... na zalost...kompleksas...tanak karakter...".Миљан Максимовић: "Прави човек ...Велики писац...Није заборавио своје порекло...". Hasib Zinka: 
"Tako je moj Nedime cvaki koji se "uda"i predje na zenino". Kadiric Nedim: "Jeste Miljane, bas nije zaboravio svoje "poreklo".....svoj najboji roman zapocinje sa "Bismillah rahmanirahim"....ne primjetih da je zapoceo sa "U ime oca i sina i svetoga duva".....".

Dragana Kusljic: "Nije vazno kako pocinje roman, vazno je sta pise u tom romanu, a pise da ste negde na "pola puta", ("Dervis i smrt")". Anita Gudelj: "Mesa, neponovljivi. Jedan i jedini.Obozavam svaku njegovu ric! "

Полемика се завршава овом помирљивом реченицом написаном негде у Далмацији, на шта указује "рич", али указује на дубоки јаз по питању идентитета између Срба и Бошњака у првом реду и на непомирљивост у ставовима. Тако је питање идентитета и припадности писаца са територије бивше СФРЈ одређеном корпусу националне књижевности одавно изашло из књижевноисторијских оквира, а непомирљивост која по овом питању постоји у књижевним круговима, широко је распрострањена и међу читаоцима.

Што се тиче Селимовићевог најзначајнијег дела и једног од највећих романа српске књижевности Дервиш и смрт,те квалитета и квантитета његовог присуства на Фејсбук страници посвећеној великом писцу, не може се рећи да је он изостављен, али није заступљен у мери која је очекивана, с обзиром на већ истакнут значај и популарност који има у стручној и читалачкој јавности. Ако погледамо структуру и садржај постова који доминирају страницом, јасно је да читаоце у већој мери занимају личне теме које се баве душевним животом човека, љубављу, односима међу људима у микро окружењу блиских односа, а у мањој мери теме људске егзистенције, смисла живота, филозофским и идеолошким питањима судбине човека у свету и друштву. С обзиром да Дервиш разматра ова врхунска питања смисла људске егзистенције и утицаја друштва на појединца, јасно је зашто цитати из овог дела нису доминантни на овој страници. Да ли то указује на површност њених посетилаца или на све веће затварање људи у сопствени микро свет изван којег их мало шта занима, не можемо са сигурношћу да тврдимо, али смо склони да верујемо да је у питању ова друга претпоставка. Наиме, у савременом свету који постаје све несигурније и опасније место услед свима познатих глобалних претњи, постоји јака тенденција затварања у 
свој приватни свет, наизглед заштићен од спољних удара, као одраз својеврсног затварања очију пред застрашујућим светом и бекства у микро окружење. Ово је , по нама, један од основних узрока зашто су цитати из романа Дервиш и смрт заступљени у мањој мери од цитата из Селимовићеве лирске прозе на овој страници и указују на "модерност" њених посетилаца, ако под њом подразумевамо уклапање у водеће светске трендове развоја људског друштва и појединца. Као пример цитата из романа Дервиш и смрт, одабрали смо онај који се често понавља на страници, познату мисао која је донекле прешла међу изреке: „Хиљаду се пута покајеш за оно што кажеш, ријетко за оно што прешутиш, знао сам ту мудрост кад ми није била потребна“. Коментари на овај пост су по правилу други цитати из Дервиша, уз понеку кратку опаску попут "Вала то је тачно", или "Мудрост долази накнадно". Овде по правилу изостају полемике, као и псеудофилозофска разматрања и исповести, што може да указује на све раширенију потребу избегавања "великих" тема и тражења коначних одговора међу просечним љубитељима књижевности, какви су већином посетиоци ове странице.

Кратка анализа Фејсбук странице посвећене Меши Селимовићу отклања наведену сумњу да у савременом интерактивном окружењу хипермедија класици културе постају потрошни медијски садржај, док истовремено потврђује већ традиционални раскорак између стручне рецепције одређеног књижевног дела и рецепције ширег читалачког круга, који се огледа првенствено у избору дела која се налазе у фокусу пажње у овом конкретном случају. Ипак, оно што представља неспорну вредност и новину, јесте чињеница да по први пут, захваљујући друштвеним мрежама попу Фејсбука, можемо да прецизније сагледамо забележене реакције и коментаре конкретних људи који спадају у најшири круг читалаца једног одређеног писца. До сада су се бележењем својих ставова, судова или рефлексија о одређеном књижевном делу бавили претежно стручњаци, тееоретичари и критичари, те људи од пера, а ставови најширег читалачког круга су били ретко бележени. За сваког ствараоца би била драгоцена могућност да сагледа обим и квалитет рецепције свог дела, да ослушне своје читаоце, а за књижевну теорију и критику се на овај 
начин отварају многа нова поља истраживања, првенствено на пољу рецепције књижевног дела. Блискост коју читаоци осећају према делу Меше Селимовића, а о којој је већ било речи, потврђује се и кроз непосредно обраћање писцу на овој страници, полемисање и расправе, као са блиским пријатељем и(ли) сопственим одразом у огледалу. То нас наводи и на закључак да истинске и најдубље вредности уметничког дела својим универзалним значењем и зрачењем остају препознате и трајне, без обзира на образовање, искуство или изграђеност укуса оних који то дело препознају као део своје духовне баштине. На питање да ли и у којој мери овакве странице проширују комуникационо поље делима високе културе, гледајући на бројке, можемо дати недвосмислено потврдан одговор, али за прецизније одговоре, попут квалитета те рецепције, потребна је детаљнија анализа садржајних и идејних слојева овако сложеног и вишезначног интертекста. У сваком случају, и поред реалне могућности површног интерпретирања садржаја, јасно је да овакве странице посећују претежно љубитељи књижевности и писане речи, шароликог знања и образовања, трагаоци за одговорима о смислу живота, о љубави, о људским односима, за поукама и путоказима у савременој шуми мноштва контрадикторних информација, а у тој потрази поклањају поверење провереним и блиским вредностима, са којима могу да се слажу, да их преиспитују, да ступају у интерактиван однос, водећи жив дијалог са светом и самим собом. Човек остаје, упркос свему, биће које перманентно помера своје границе, за кога је много важније да проучава оно што може да постане од онога што јесте, а у виртуелном окружењу хипермедија налази једно од могућих идеалних поља за сопствено преиспитивање, огледање и стални дијалог са највреднијим претходницима и савременицима.

\section{Извори и литература}

Барт, Роланд. Смрт аутора, у: Сувремене књижевне теорије, прир. Мирослав Бекер, Загреб: СНЛ, 1986.

Вучковић, Радован. "Српски роман у контексту егзистенцијалистичког романа". Јован Делић (прир.). Меша Селимовић, Нови Сад: Издавачки центар Матице српске, 2014. 
Глушчевић, Зоран. "Меша Селимовић: Магла и мјесечина". Јован Делић (прир.). Меша Селимовић, Нови Сад: Издавачки центар Матице српске, 2014.

Делић, Јован. "Златна деценија Меше Селимовића". Предговор у: Меша Селимовић, Нови Сад: Издавачки центар Матице српске, 2014.

Ерор, Гвозден. Генетички видови интер(литерарности), Београд: Откровење/ Народна књига, 2002.

Ерор, Гвозден. "О појму књижевног хипертекста". Књижевна историја, вол.33 бр.113-115 (2001): 5-38.

Егерић, Мирослав. "Човек и судбина у Тврђави Меше Селимовића". Јован Делић (прир.). Меша Селимовић, Нови Сад: Издавачки центар Матице српске, 2014.

Јерков, Александар. "Културна поетика прозе Меше Селимовића". Предраг Палавестра (ур.). Споменица Меше Селимовића, Београд: Српска академија наука и уметности, 2010.

Катнић-Бакаршић, Марина. Стилистика, Сарајево: Научна и универзитетска књига, 2007.

Крстић, Марко. "Круг или финале породичног усуда". Предраг Палавестра (ур.). Споменица Меше Селимовића, Београд: Српска академија наука и уметности, 2010.

Селимовић, Меша. Дервиш и смрт, Сарајево: Веселин Маслеша: 1981.

Селимовић, Меша. Сјећања. Београд/Ријека: Слобода/ Отокар Кершовани,1973.

Селимовић, Меша. (2014): Меша Селимовић, прир. Јован Делић, Издавачки центар Матице српске, Нови Сад.

Томашевић, Бошко. (2006): "Хиљаду равни: трансверзални ум, нелинеарно писање, књижевни хипертекст и крај Гутенбергове галаксије". Поља, бр.441 (2006): 48-56.

\section{Вебографија}

https://www.facebook.com/Mehmed.Mesa.Selimovic/?fref=ts (приступљено 31.август 2016.године)

Kurtz, G.A. (1997) From work to hypertext: Authors and authority in a reader-directed medium, http://www.glennkurtz.com/Work.html (приступљено 12.август 2016. године) 


\title{
Maja Radonić
}

\section{DIGITAL MEDIA AND LITERATURE - THE LITERARY CLASSICS ON SOCIAL NETWORKS.}

\begin{abstract}
Summary
Digital technology has opened an almost unlimited field of new opportunities to create and transfer information and diverse content via digital media. In the virtual space of the Internet, beside the dominant entertaining and informative contents, there is a place for works and creators of permanent cultural values, such as literary classics. The example of the Facebook page dedicated to the great Serbian writer Mesa Selimovic seeks to determine whether and how hypermedia, represented by this interactive page, expand the communication field of a literary classic, whether they contribute to a deeper understanding of the specific content of high culture, and to what extent they bring a potential danger of its superficial, mass-media interpretation? In other words: is it possible that in the modern interactive environment of hypermedia, cultural classics become expendable media content? Beside the definition of the basic problem framework, this paper observes that hypermedia like this internet page, represent, to a large extent, a new form of inter-text, which is a result of and is developing in a changing interactive environment.
\end{abstract}

Key words: digital media, reception, internet, Mesa Selimovic, Facebook, literature, interactivity 